\title{
Holy Hills Role in Biodiversity Conservation and Mountain Management: Implication of Multi-Purpose Ethiopian Orthodox Tewahido Church in Sustainable Mountain Conservation
}

\section{Tura TT, Soromess T, Argaw M and Leta $\mathbf{S}^{*}$}

Center for Environmental Science, College of Natural and Computational Sciences, Addis Ababa University, Addis Ababa, Ethiopia

\begin{abstract}
Ethiopia had practiced Judaism before Christianity. This church is unique in the continent of Africa and glob in holding judo-Christian sect. In the church tradition forests are considered as shelter of the earth crust which provides enormous scenery to the world. Most of the Ethiopian Orthodox Tewahido Church and monasteries are built on hills, mountains and high places which are covered with densely forests. This practice and tradition was comes from Eden, the place had all the best and choicest trees and plant, God a tender Father, provide not only for Adam's needs, but also his pleasure. The church on the earth signifies the new heaven, the holy city, New Jerusalem, coming down from God out of heaven, prepared as a bride adorned for her husband, Adam. Therefore, gardening was the first kind of employment on record in which man was engaged. Though trees and plants produced the necessary flower and fruits by the will of God, dressing and keeping are necessary to maintain in their perfection. The greenery in Eden is the underlying principles on which Ethiopian Orthodox Tewahido Church dwell to conserve nature. Existing literatures on the nature conservation role of Ethiopian Orthodox Tewahido Church is not the detail. Therefore, published articles and Holy Scriptures were reviewed and presented in a more coherent manner. The main objective of the paper is to explore past and present work on sacred grove role in general, Ethiopian Orthodox Tewahido Church in particular in mountain ecology management and biodiversity conservation. The result shows that unreplaceable role of Ethiopian Orthodox Tewahido Church in conserving forest and mountain biodiversity in Ethiopia by indicating large scale forests and ecosystem is currently under the custodianship of Ethiopian Orthodox Tewahido church and its role on carbon emission reduction in the changing world. Therefore, recognizing the indigenous knowledge in biodiversity and mountain conservation and customizing the best practice from it would help global efforts on remnant resource conservation. It is a win-win scenario for diversity management and mountain conservation policy formulation effort too.
\end{abstract}

Keywords: Biodiversity conservation; Church forest; Ethiopian orthodox; Tewahiodo church; Holly hills; Mountain conservation

\section{Introduction}

Indigenous knowledge has been seen as backward, inert and an impediment to modernization [1,2], stated similarity and difference between scientific and indigenous knowledge; ways of harmonizing in order to contribute for sustainable development goals. Science and indigenous knowledge differ in their capacity to deal with local problems [3,4]. Indigenous knowledge is often based on long time experience of a specific phenomenon and places while scientific knowledge describes detail process at a point in time [5,6], claimed that scientific knowledge has contributed very little to the development of rural societies around the world; a compared to indigenous knowledge. Similarly natural resource management in developing countries often mimics the western model by the overlooking indigenous cultures and institution. But now indigenous knowledge recognized as extensive, sophisticated, unique, and complex body of knowledge $[7,8]$.

The Ethiopian Orthodox Tewahido Church (EOTC), an indigenous and integral Christian Church of Africa, is one of the oldest Churches in the world and founding member of the World Council of Churches [9]. Ethiopia embraced Christianity and maintained the doctrine of Christ from the era of the Apostles to the present day as it is narrated in the Holy Bible (Acts 8:26-39). It has over 45 million followers, more than 400,000 clergies and 35,000 churches, several Archbishops and dioceses [10]. The Church has long history on planting, protecting and preserving of forest [9]. This indicates a cumulative knowledge of spiritual mediums, teaching philosophy, the wise council of elders and the leadership of religious leaders, institutions in managing and conserving resources and strong sanctions for Outliers $[9,11]$. However, the role of Ethiopian Orthodox Church is not well recognized and documented. Therefore, in this review work, we organized Holy Scriptures, church scholars teaching and published literature on mountain and biodiversity conservation role of the church in more coherent way for current scientific demand in the pillar of world mountain and biodiversity conservation.

\section{Materials and Methods}

\section{Study site description}

The study area is Ethiopian Orthodox Tewahido Church. It is the ancient church and the first in terms of the number of followers in the country. The church is found all over the country which has diverse climate and physiographic conditions. Ethiopia lies within tropics of $3^{\circ} 24^{\prime}$ and $14^{\circ} 53^{\prime}$ North; and $32^{\circ} 42^{\prime}$ and $48^{\circ} 12^{\prime}$ East. It covers $1,120,000$ square kilometers and administrated in nine regional states, one City Council and one City Administration [9].

*Corresponding author: Seyoum Leta, Center for Environmental Science, College of Natural and Computational Sciences, Addis Ababa University, P.O. Box 1176, Addis Ababa, Ethiopia, Tel: +251-9-11-90-70-38; E-mail: seyoum.leta@aau.edu.et; tulutollatura@gmail.com

Received December 16, 2016; Accepted January 19, 2017; Published January 27, 2017

Citation: Tura TT, Soromess T, Argaw M, Leta S (2017) Holy Hills Role in Biodiversity Conservation and Mountain Management: Implication of Multi-Purpose Ethiopian Orthodox Tewahido Church in Sustainable Mountain Conservation. J Biodivers Endanger Species 5: 179. doi: 10.4172/2332-2543.1000179

Copyright: $\odot 2017$ Tura TT, et al. This is an open-access article distributed unde the terms of the Creative Commons Attribution License, which permits unrestricted use, distribution, and reproduction in any medium, provided the original author and source are credited. 
Citation: Tura TT, Soromess T, Argaw M, Leta S (2017) Holy Hills Role in Biodiversity Conservation and Mountain Management: Implication of Multi-Purpose Ethiopian Orthodox Tewahido Church in Sustainable Mountain Conservation. J Biodivers Endanger Species 5: 179. doi: $10.4172 / 2332-2543.1000179$

Page 2 of 10

The geographical location of Ethiopia is $09005^{\prime} \mathrm{N}$ to $09000^{\prime} \mathrm{N}$ latitudes and $38045^{\prime} \mathrm{E}$ to $38042^{\prime} \mathrm{E}$ longitude. The maximum and minimum altitude of the country is $4,620 \mathrm{~m}$ and $126 \mathrm{~m}$ above sea level respectively. The country receives annual mean rainfall of 900 $\mathrm{mm}$ and $600 \mathrm{~mm}$ respectively and $34.5^{\circ} \mathrm{C}$ and less $0^{\circ} \mathrm{C}$ is maximum and minimum temperature, respectively. Ethiopia is the third most populous country in Africa next to Egypt and Nigeria with more than $80,000,000$ populations and 85.3 percent of the population lives in rural areas (Figure 1) [12].

\section{Agro-Ecological Distribution of EOTC}

The Federal Democratic Republic of Ethiopia (FDRE) is a landlocked country in the horn of Africa, bounded by Eritrea, Sudan, South Sudan, Kenya, Somalia and Djibouti. Ethiopia has tremendously assorted topography [13]. The multifaceted geological processes began long ago that caused unevenness of the surface, a highland intricate mountains and bisected plateau features. Scholars estimated that about $45 \%$ land mass is accounted for mountains area of about $500,000 \mathrm{~km}^{2}$. These areas are home for about $88 \%$ of the population; more than two thirds of livestock population; $95 \%$ of the cropped lands and $90 \%$ of the economic activities [14]. It has an altitude of $126 \mathrm{~m}$ below sea level at Dalol depression to 4,620 m at Ras Dejen Mountain The plateau in the northern and the south is bisected by the East African Rift Valley. The rift then descends to the northeast and its lateral escarpments begin to diverge from each other crossing the Afar depression toward the Red Sea coast.

Climatic elements such as precipitation, temperature, humidity, sunshine and wind are affected by geographic location and altitude. Ethiopia, being near the equator and with an extensive altitude range, has a wide range of climatic features endowed with high biodiversity. The $4620 \mathrm{~m}$ has low temp while low land has high temp from the mean annual of $34.5^{\circ} \mathrm{C}$ with a mean of less than $0^{\circ} \mathrm{C}$, where light snowfalls are recorded in most years. Between plateaus and marginal slopes has mean annual temperatures $10^{\circ} \mathrm{C}$ and $20^{\circ} \mathrm{C}$ (Figure 2).

According to FAO [15] rainfall in Ethiopia is generally correlated with altitude. Middle and higher altitudes (above $1500 \mathrm{~m}$ ) receive substantially greater falls than do the lowlands, except the lowlands in the west where rainfall is high. Generally, average annual rainfall of areas above $1500 \mathrm{~m}$ exceeds $900 \mathrm{~mm}$ while lowlands of $1500 \mathrm{~m}$ are erratic on averages below $600 \mathrm{~mm}$ (Figure 3) [13].

The Ethiopian multitude Agro-Ecological Zones (AEZs) are traditionally classified into five categories with traditional names assigned to each zone, based on altitude and temperature. Bereha, kola weinadega, dega and Wurch (Table 1). However, the amount of rainfall and its distribution are also important in classifying common agroecological zones (Figure 3). It is common to associate the traditional zones with elevation and temperature and researchers have classified the vegetation and ecological zones too (Table 1) [16,17].

In a similar manner within these extremes agro-ecological zone there are a number of ancient Ethiopian Orthodox Tewahido churches and monasteries. Most of those churches and monasteries are endowed with natural forests which is rich in plant and animal diversity [9]. Ethiopian Orthodox Tewahido church has well organized administration hierarchy from top to bottom which helps natural resources administration and provide spiritual and social services for her followers (Figure 4).

The Offices of the Dioceses are those church offices in each diocese under the office of patriarchate. Generally, EOTC has 64 Dioceses, 50 are distributed throughout the country and 14 are outside of the country. Every Diocese is headed by Archbishop and departmentalized in to different administration and developmental department. The numbers of Dioceses are in line with zonal political administration of the country except in some regions (Figure 5). All churches and lower administrative parts are directly accountable for their respective Dioceses if their issues not managed at parish church council level. Therefore, the EOTC resources directly managed under dioceses next to parish church council in their respective church and monastery (Figure 5).

Note: The extreme desert (between $500 \mathrm{~m}$ and $126 \mathrm{~m}$ ) area is not traditionally classified.

Parish Council Organization is the laity and the clergy could jointly run and serve the church. Each member of Ethiopian Orthodox Tewahido Church family is registered member of the parish council organization at its parish church and entitled to all spiritual services

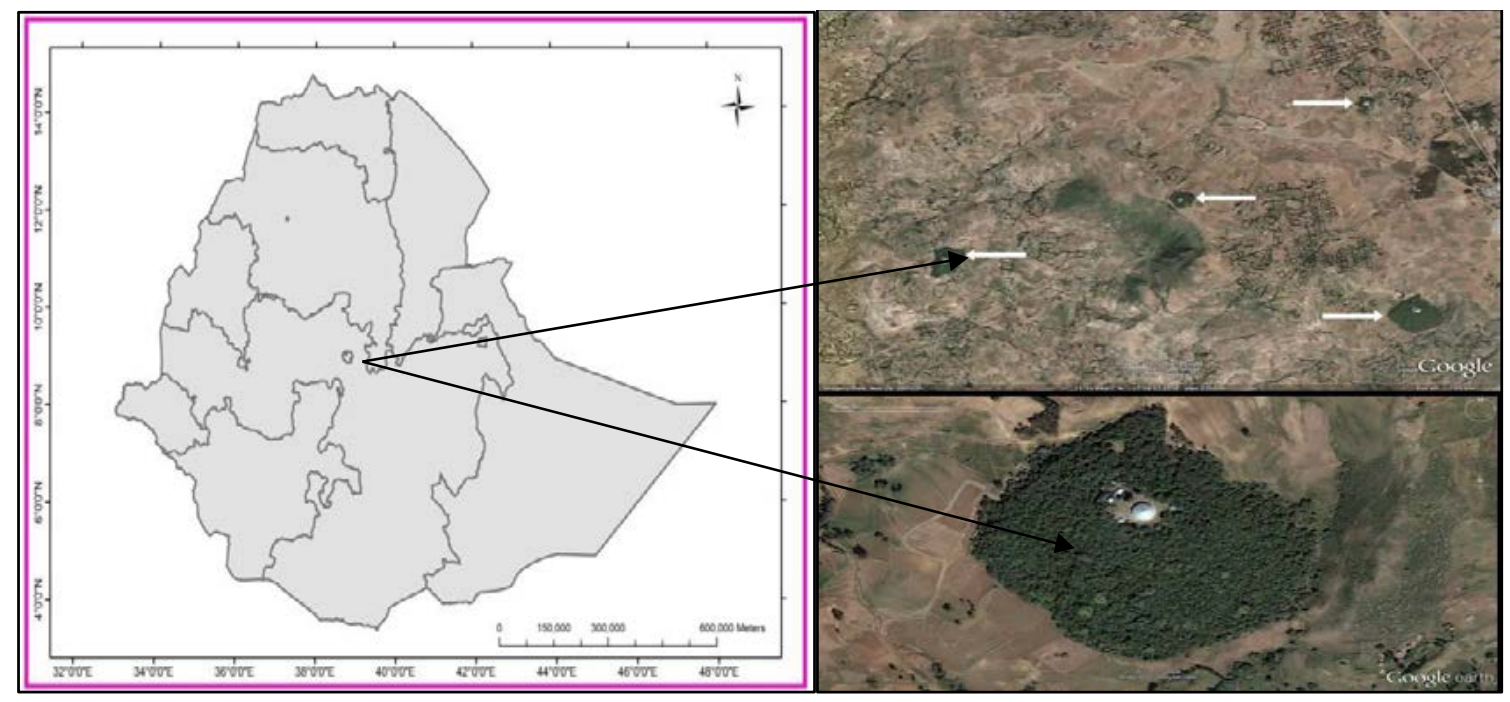

Figure 1: Ethiopian Orthodox Church forest in the degraded land (Source: Google Earth) 
Citation: Tura TT, Soromess T, Argaw M, Leta S (2017) Holy Hills Role in Biodiversity Conservation and Mountain Management: Implication of Multi-Purpose Ethiopian Orthodox Tewahido Church in Sustainable Mountain Conservation. J Biodivers Endanger Species 5: 179. doi: $10.4172 / 2332-2543.1000179$
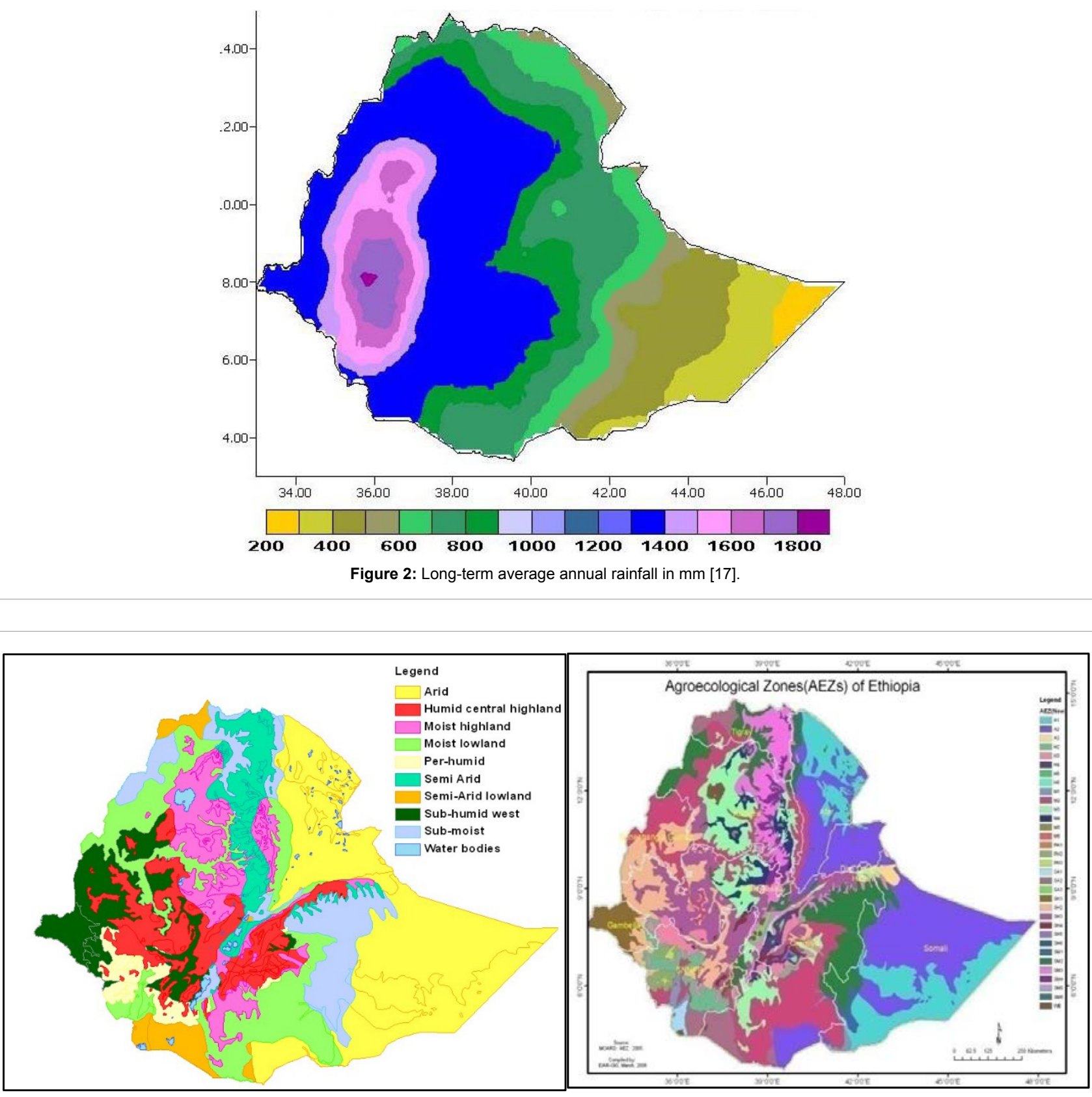

Figure 3: The meta agro-ecological zones and 32 AEZ classifications of the ministry of agriculture [17].

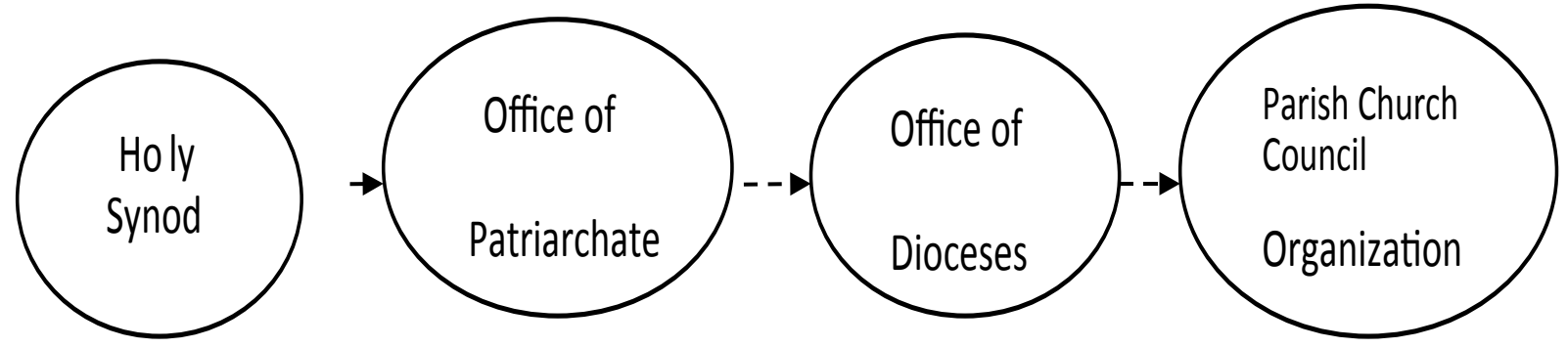

Figure 4: The main administrative hierarchy of the ethiopia orthodox tewahido Church. 
Citation: Tura TT, Soromess T, Argaw M, Leta S (2017) Holy Hills Role in Biodiversity Conservation and Mountain Management: Implication of Multi-Purpose Ethiopian Orthodox Tewahido Church in Sustainable Mountain Conservation. J Biodivers Endanger Species 5: 179. doi: $10.4172 / 2332-2543.1000179$

Page 4 of 10

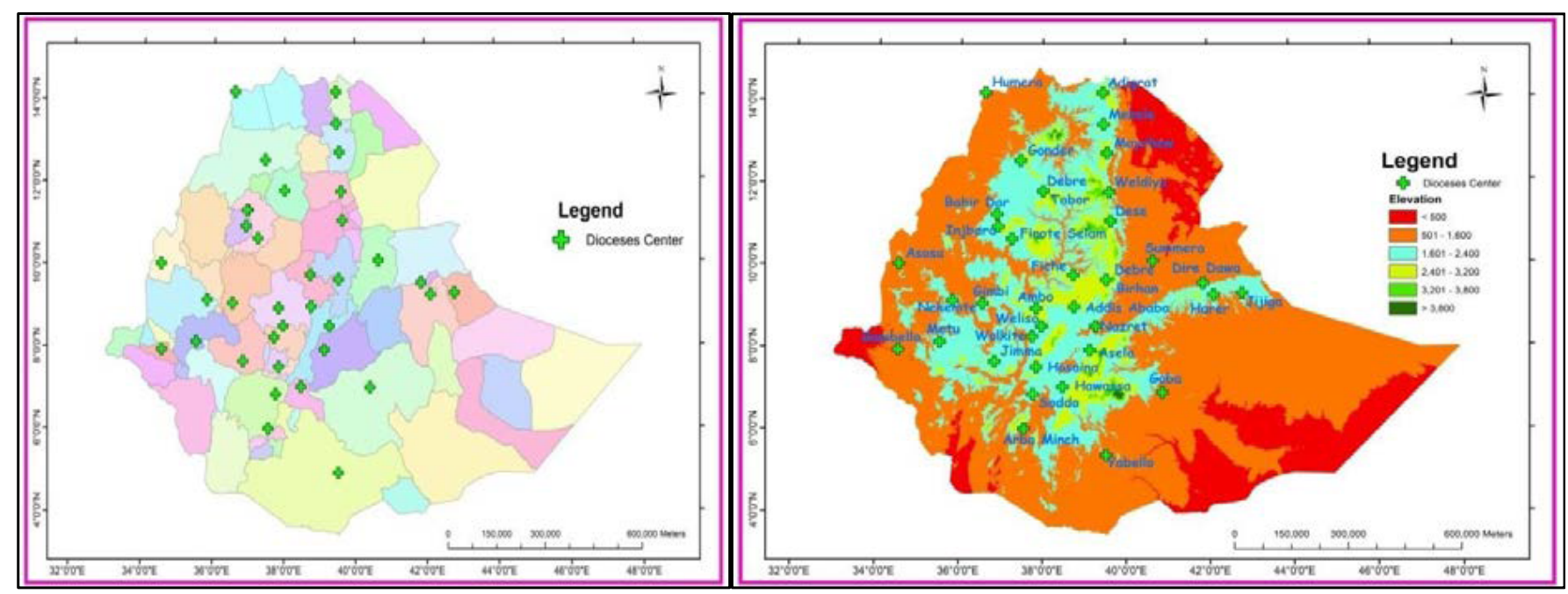

Figure 5: Ethiopian orthodox tewahido church dioceses agro-ecological distribution.

\begin{tabular}{|c|c|c|c|}
\hline Zone & Altitude $(\mathbf{m})$ & $\begin{array}{c}\text { Mean rainfall } \\
(\mathbf{m m})\end{array}$ & $\begin{array}{c}\text { Temperature } \\
\left({ }^{\circ} \mathbf{C}\right)\end{array}$ \\
\hline Bereha (Dry-hot) & $500-1500$ & $<900$ & $>22$ \\
\hline Weinadega (Dry-warm) & $1500-2500$ & $<900$ & $18-20$ \\
\hline Erteb Kola (Submoist warm ) & $500-1500$ & $900-1000$ & $18-24$ \\
\hline Weinadega (Submoist cool) & $1500-2500$ & $900-1000$ & $18-20$ \\
\hline Ertebweinadega (Moist-cool) & $1500-2500$ & $>1000$ & $18-20$ \\
\hline Dega (Cold) & $2500-3500$ & $900-1000$ & $14-18$ \\
\hline Ertebadega (Moist cold) & $2500-3500$ & $>1000$ & $10-14$ \\
\hline Wurch (Very cold or alpine) & $>3500$ & $>1000$ & $<10$ \\
\hline
\end{tabular}

Table 1: Traditional Ethiopian agro-ecological zones.

at its parish church. Members of the Parish Council Organization are not only beneficiaries of spiritual services they also build churches, facilitates to generate income for their parish church, and support their church in any way required.

\section{Sacred institution role in nature conservation and climate change mitigation}

Sacred groves might be smaller or larger ecosystems originated from lacerate and blaze system of agriculture left standing around farmlands with and without organized institution services as center for culture and religious life $[9,18]$. There are several relicts, endemic and endangered species have been recorded in sacred groves which administrated under sacred institution in their respective localities. Therefore, sacred institutions are a model for in situ conservation sites and acts as a refuge for endangered and extinct species which becomes ecologically important in the glow of current rates of deforestation and loss of species [19].

The secret behind the conservation success of most sacred institution are taboos and social sanctions on outliers of social custom [20-23], which indicates global sacred institution experiences on conserving trees in the name of religion and culture with various doctrine of the religions and cultures [24-26]. This indigenous religiocultural institution practice is not only meeting the economic and ecological needs of the people, but also an integral part of their culture and spiritual tradition [27-32].

Sacred institutions have long and diverse history in human cultures and demonstrate long time (ancient) connection between peoples and their environment. It is a universal human phenomenon and not associated with specific religion but they have a strong religious context and influenced by local beliefs [33-35]. Many studies have revealed the importance of indigenous institution cooperation in the conservation of nature $[23,28,36]$. However, rapid globalization process as well as lack of capacity and facilities to document, evaluate, validate and protect; causes indigenous knowledge becoming threatened and extinct [37-39].

In addition to its role for the nature conservation, sacred cultural and religious aspects behind sacred institutions are potential for climate change prediction and shock resistance [40], however, the emphasis on consumption, economics and policy usually fail to engage people at any deep level because it does not address the narrative, the mythological, the metaphorical or the existence of memories of past disasters and the way out $[41,42]$. The faiths are the holders of these areas and without them policies will have very few real roots. Religious practices can not only ameliorate hardships affecting communal life, but also animate calls for alternative value systems and lifestyles as well as knowledge about the weather and its effects on local ecology and physical landforms [40]. Some scholars deemed the sense that Biblical Flood as divine punishment induced by human sin [43]. This is in line with the belief expressed by eco theologian "Global warming is the Earth's judgment on the global market Empire and the reckless consumption it fosters" [44]. The two ideologies agreed on the moral failures of humanity's cause of global climatic change, whether mediated by God or by the Earth, therefore, without understanding the religious and spiritual dimensions of life worlds, climate change communication, advocacy campaigns and policy development and implementation will be deficient. In general, a Christian theological perspective investigation might be enclosed about 'creation care', 'neighbor care' and eschatology [45].

Most scholars agreed on religious thought and belief help us to understand the climate change and its solution [46-48]. This is not dissimilar to the current call for environmental action [49]. It is a cofunction of growing interest in how institutions, communities and individuals engage in adaptation actions to reduce vulnerabilities to extreme weather [50]. 
Citation: Tura TT, Soromess T, Argaw M, Leta S (2017) Holy Hills Role in Biodiversity Conservation and Mountain Management: Implication of Multi-Purpose Ethiopian Orthodox Tewahido Church in Sustainable Mountain Conservation. J Biodivers Endanger Species 5: 179. doi: $10.4172 / 2332-2543.1000179$

Page 5 of 10

\section{Sacred grove in mountain conservation}

In the Old Testament, before the revelation of God to the prophets, there was no specific place where people ought to worship the true God and offer sacrifice; instead top of hills and mountains are places of worship for them which is covered with trees and other plants [9]. Mountain and hills played a significant role in the relationship between beings and Almighty 'Noah expressed his gratitude for deliverance from the flood by making an altar and presenting burnt offerings unto the Lord. The place where the ark rested and the altar built was Mount Ararat. God appeared to Abraham and told: "Take now thy son, thine only son, Isaac, whom thou lovest, and get thee into the land of Moriah; and offer him there, for a burnt offering upon one of the mountains which I will tell thee of".

The Holy Bible states about Eden as "And the Lord God planted a garden east-ward in Eden; and there he puts the man whom he had formed. And out of the ground made the lord God to grow every tree that is pleasant to the sight, and good for food...And a river went out of Eden to water the Garden; and from thence it was parted, and became in to four heads. " (Genesis 2: 8-10). Because mountains are symbolise the strength and stability, sources of strength, strength of the kingdom of God, the righteousness of God, persons in authority, difficulties.

Castro and Aldunate [51] stated sacred grove's sanctity role in mountain conservation. In the similar way the role of sacred grove in natural geography and land escape protection is significant $[25,52]$. Restoration and protection of Holly hills play very important role in biodiversity protection and overall ecological functioning [53]. Other researchers demonstrated that sacred forests have persisted longer than non-sacred forest in the ocean of deforestation $[54,55]$.

Sacred grove forests are high diversity and complex structure when compared with non-sacred forests which might have sanctity and grazing restriction [56,57]. In a similar way, sacred groves are world's heritage for nature conservations; especially for protecting and preserving endemic and endangered species [58-60].

Sacred geographical features are assortment of a sacred tree which resides in a sacred grove on a sacred mountain [61]. This confluence of ecotypes results in extraordinary biodiversity in mountain region is one of the global hotspots [62,63], examined the relationships among sacred sites, elevation and vegetation with Geographical Information Systems (GIS) and indicated that sacred sites are found to have more species and diverse habitats than randomly selected non-sacred sites.

\section{Christianity in mountain conservation}

According to Holly Bible (Matthew 5:17-19), the New Testament is strengthens the Old Testament. The New Testament does not explicitly mentioned nature conservation, except fruit bearing species such as the fig and palm tree [64]. Since Jesus did not reject the laws of the Old Testament and pleaded to follow those in his Sermon on the Mount (Matthew, 5) indicated the laws and environmental ethics of Moses stated on the Old Testament are also relevant for Christianity.

As stated on Holly Bible Jesus Christ teaches his follower on mountain (Matthew, 5:1). The commentary of Matthew (5:1) indicates that; mountain is symbol for strength, stability, freedom, and roughness. Jesus Christ teaches on mountain to indicate the historical relationship between mountain, Old Testament and New Testament because mosses formulated Old Testament on mountain. This indicates the strong relationship between mountain and Christianity. Jesus Christ symbolized his divinity as; "I am the true vine, and my father is the husbandman. Every branch in me that beareth not fruithe taketh away: and every branch that beareth fruit, he purgeth it, that it may bring forth more fruit.... I am the vine, ye are the branches" (John 15: 1-5). In this statement it is shown that the Lord and Savior Jesus Christ as a vine tree, believers as the branches and his relation to them as the source of all their fruitful and spiritual life. This indicates the relation between trees, Divinity and humanity.

Another sentence explicitly states the relationship between New Testament, tree, water and Divinity in Revelation (22: 1-2). "And he showed me a pure river of water of life, clear as crystal, proceeding out of the throne of God and of the lamb. In the midst of the street of it, and on either side of the river, was there the tree of life, which bare twelve manners of fruits and yielded her fruit every month; and the leaves of the tree were for the healing of the nations".

The Arc of Noah through which man was saved from the evil distraction of water was made of wood and rest on mountain. Old Testament stated care for nature and animal very well (Leviticus 24; Deuteronomy 22). On Genesis stated that; "In the beginning God created the heavens and the earth and made every one of them, then he looked at what he had done, and it was good (Genesis 1)". This indicate the existence of every life and nature in this world is a will of God; therefore, any one acting on the nature unethically is uncompromised the vision of God for his creation.

\section{Ethiopian orthodox tewahido church role in mountain conservation}

Sacred groves symbolized globally with different names and purposes; which known as church forests, fetish forests and sacred forests $[65,66]$. Therefore, forests and trees enclosed in churches and monasteries are tantamount with the phrase sacred groves in most literature $[9,67]$.

The main theological bases and religious perspective in conserving biodiversity at churches and monasteries compounds is "the Church on the earth signifies and symbolizes the new heaven, the holy city, New Jerusalem coming down from God out of heaven, prepared as a bride, adorned for her husband" [9]. New Heaven (Eden) stated on Holy Bible as "And the Lord God planted a garden east-ward in Eden; and there he puts the man whom he had formed. And out of the ground made the lord God to grow every tree that is pleasant to the sight, and good for food...And a river went out of Eden to water the Garden; and from thence it was parted, and became in to four heads. " (Genesis 2: 8-10). The phrase 'Out of the ground made the Lord God to grow every tree that is pleasant to the sight' which indicates ecological design of Lord not only for human consumption. God left the first man with tasks along freedom and pleasure he had in eden "And the Lord God took the man, and put him in to the Garden of Eden to dress it and to keep it" (Genesis 2: 15).

Therefore, the Ethiopia Orthodox Tewahido Church followers who are supposed to be the generation of Adam and children of God should esteem and practice this dictated at least in the church compound (Figure 6) [9].

As stated by Cohen and Weintraub [68], one third of Ethiopia land was belonging to the church before the 1974 revolution. According to Catherine and coworkers average church and monastery forests located at kilometers and half above sea level with mean of $2334 \pm 9 \mathrm{~m}$.

\section{Climate change adaptation and mitigation role of ethiopian orthodox tewahido church}

Climate change adaptation actions and locally developed climate change adaptation and mitigation strategies unnoticed the inherent 
Citation: Tura TT, Soromess T, Argaw M, Leta S (2017) Holy Hills Role in Biodiversity Conservation and Mountain Management: Implication of Multi-Purpose Ethiopian Orthodox Tewahido Church in Sustainable Mountain Conservation. J Biodivers Endanger Species 5: 179. doi: 10.4172/2332-2543.1000179
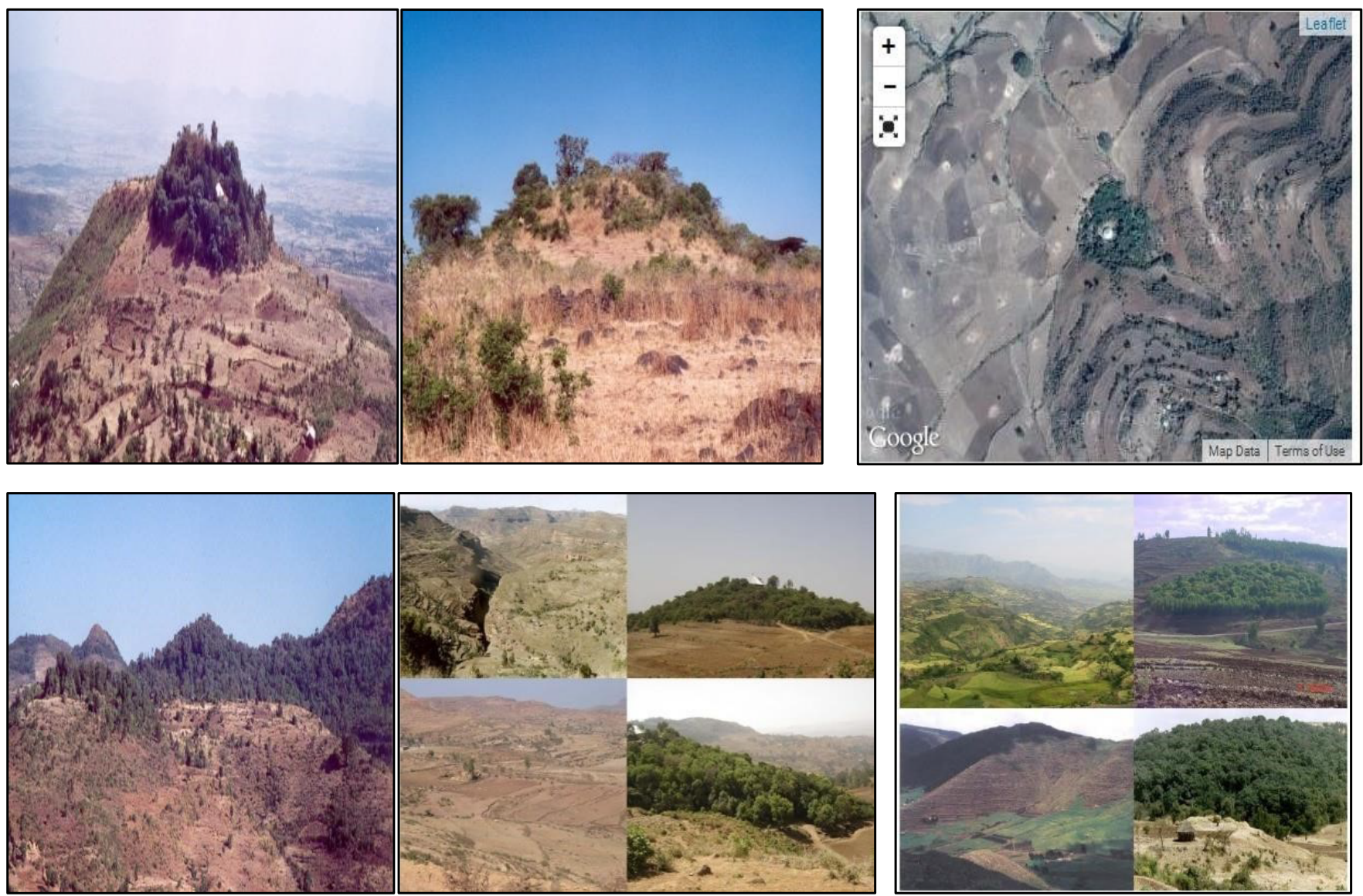

Figure 6: Monasters and church role in mountain conservation (Source: Google).

knowledge of local community. However, researchers finding stated that effectual climate change adaptation measures and mitigation strategies are found within the local communities while climate perception and attitude plays significant role in climate change risk reduction and avoidance with degree of available adaptation tools vary from one community to another [69-72].

In a similar way Ethiopian Orthodox Tewahido church plays significant role on building public perception and attitude causes and consequences of climate change and implementation of climate change adaptation strategy in addition to direct carbon sequestration through forests in monastery and church compounds. The main social purpose of Ethiopian Orthodox Tewahido churches and monasteries are places for worship, burials and meditating religious feasts and festivals in addition to tenable habitats for plants and animals, as well as living organism $[9,73]$. This provide gold opportunity for the church to guiding, teaching and preaching her followers regarding goods, terrible and coming global concerns including causes and consequences of climate change, appropriate mitigation and adaptation measures.

Most wood species in monastery and church compounds are endemic to afro-mountain vegetation type which is center for plant genetic diversity and opportunity for climate change mitigation [74]. The unique characteristics of afro-mountain forest ecosystem are its diversity and richness in endemic species [75], study stated that, carbon sequestration potential of church forest is comparable with other national and tropical natural forest (Figure 7).
Even if the phenomenon of deforestation has been occurring in the vicinity; the monastery and church forests are kept as it is with minimum disturbance and covers one third land of the country in the past $[68,73,76-79]$. This indicates carbon in church and monastery forests are kept in highly secured bank for a century.

\section{Religious thought and tradition of Ethiopian orthodox Tewahedo church in nature conservation}

Ethiopian orthodox tewahedo Church is an ancient native basilica in Africa [9]. The traditions of planting, taking heed of, and preserving trees is a long history in the church. The spiritual bond between tree planting, conserving and protecting is based on the Holy Scriptures and church Scholars thought. The commencement of the creation history stated that "the earth was without form and was void. Then it was made into a habitable place and nature was adorned, that means populated with flourishing and pleasant trees. It was not an ivory house or a place overlaid with gold and silver, but a garden. The heaven was the roof of Adam's house, and never was any roof so curiously painted. The earth was his floor, and never was any floor so richly inlaid. The shadow of the trees was his retirement; under them was his dining room. The situation of the garden was extremely sweet. It was Eden, which signified delight and pleasure. The place had all the best and choicest trees and plants. God, a tender Fathe, provided not only for Adam's needs but also his pleasure. The rivers and streams with which the garden was watered contributed much both to the pleasantness and the fruitfulness" (Genesis 1: commentary). Therefore, the church on 
Citation: Tura TT, Soromess T, Argaw M, Leta S (2017) Holy Hills Role in Biodiversity Conservation and Mountain Management: Implication of Multi-Purpose Ethiopian Orthodox Tewahido Church in Sustainable Mountain Conservation. J Biodivers Endanger Species 5: 179. doi: $10.4172 / 2332-2543.1000179$
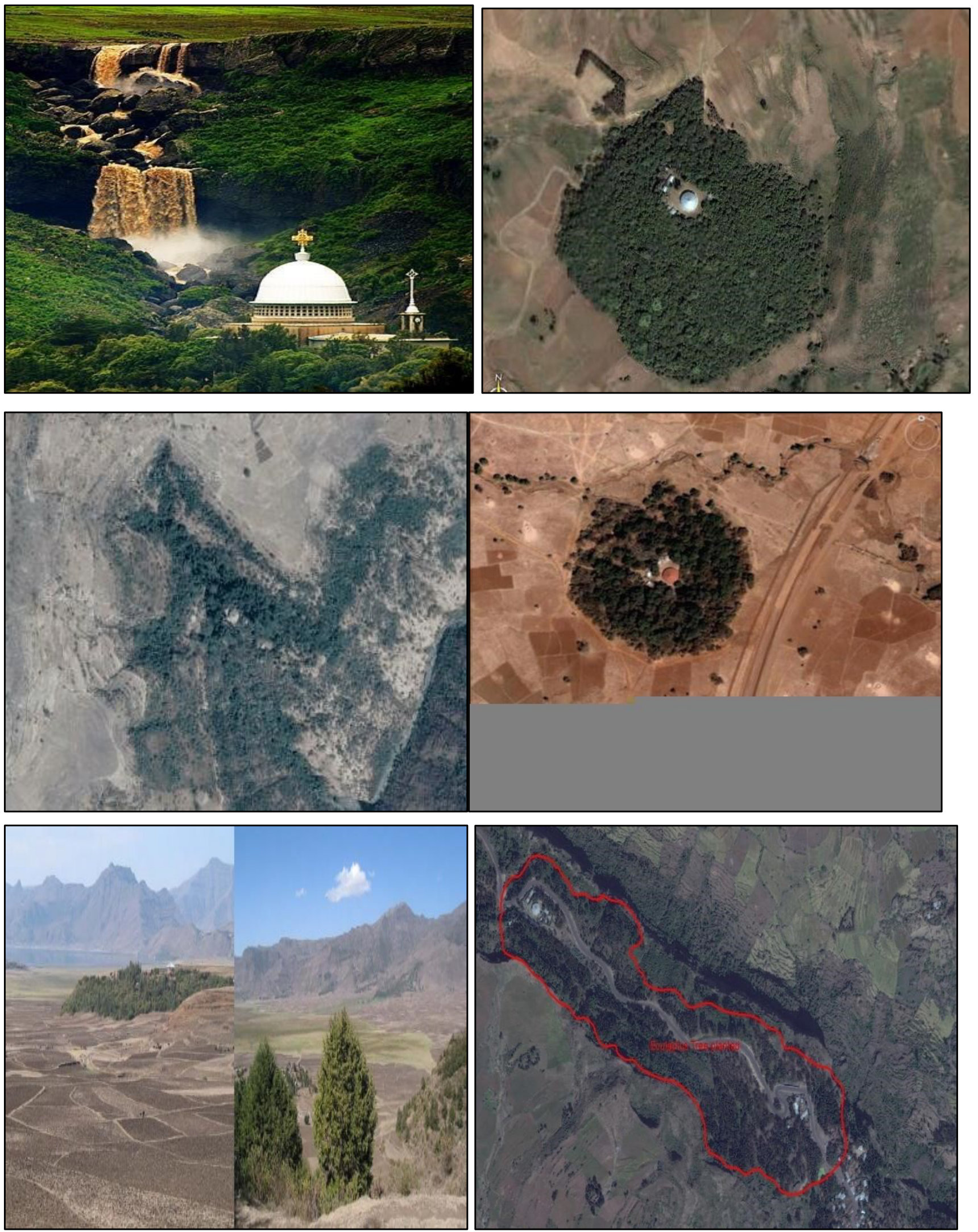

Figure 7: Monastery and church compound role in life carbon bank (Source: Google). 
Citation: Tura TT, Soromess T, Argaw M, Leta S (2017) Holy Hills Role in Biodiversity Conservation and Mountain Management: Implication of Multi-Purpose Ethiopian Orthodox Tewahido Church in Sustainable Mountain Conservation. J Biodivers Endanger Species 5: 179. doi: $10.4172 / 2332-2543.1000179$

Page 8 of 10

earth signifies the new heaven, the holy city, New Jerusalem, coming down of God out of heaven, prepared as a bride, adorned for her husband. The heavenly kingdom out of which rivers of pure water proceeded. It is visualized and believed that there are heavenly rivers infinitely surpassing the rivers of this world. They are rivers of water of life, not coming out of Eden, but proceeding out of the throne of God [9]. "And by the river upon the bank thereof, on this side, on that side, shall grow all trees for meat, whose leaf shall not fade, neither shall the fruits thereof be consumed: it shall bring froth new fruit according to his months that is twelve times in the year, because their waters they issued out of sanctuary, and the fruit there of shall be for food and the leaf for medicine" (Genesis 1).

"And the Lord God took the man, and put him in to the Garden of Eden to dress it and to keep it" (Genesis 2: 15); third day before he created the man on the sixth day. "And God said, Let the earth bring for the grass, the herb yielding seed, and the fruit tree yielding fruit after his kind, whose seed is in itself, upon the earth: and it was so: ... and God saw that it was good" (Genesis 1: 11-13). The first man residence was not an ivory house or a palace overlaid with gold and silver but a garden endowed and adorned by nature, occupied with flourishing and pleasant trees. The shadow of the trees was his retirement, under them was his dining room; and this was so good that King Solomon was not arrayed like them in his Kingdom. According to this holy statement, forests and other plants were shown how they were necessary for human worldly life and pleasure. It has also shown their right to exist in earth as long as man exists as they were created in one of the days of the creation week. So, no one has the right to destroy them except the Lord God who made them and armed with the biblical perspective, it would be suicidal to destroy them by man whom they were created for.

Trees attached with the failure of first man and Lord Jesus Christ saving process of human beings. "And the Lord God commanded the man, saying, of every tree of the garden thou mayest freely eat: but of the tree of the Knowledge of good and evil, thou shalt thereof thou shalt surely die (Genesis 2: 16-17). Sorrowfully, the first persons violated the commandment and ate the special tree. The consequence was a curse, later, based on God's promise, the Lord and the savior Jesus.

Christ came to save Adam and his generation. This was done by Jesus' holy blood, crucified on the holy cross-made of wood/special trees. This indicates eating, cutting and destroying trees without permission is causes a serious consequence. In the contrary the ark of Noah by which, he, his family and a pair of female and male animals of all types of the earth were saved from the evil destruction of water, was made of gopher wood (Genesis 6). Thus, trees and other plants are integrated with the Christian's religious life and their mere existence reminds of all the ups and downs of human beings from creation till the end of this world.

Trees and forests have been symbolized on several occasions both, in the Old and New Testaments of the Holy Bible, to remind prospects in the spiritual life of human beings with their presence and graceful habitation, and the contrary in their absence. In connection with these, some interesting biblical words can be quoted about trees. "Blessed is the man that walks eth not in the counsel of the ungodly, nor standeth in the way of sinners, nor sitteth in the seat of the scornful. But his delight is in the law of the Lord; and in his law doth he meditate day and night. And shall be like a tree planted by the rivers of water, that bringeth forth his fruit in his season; his leaf also shall not wither; and whatsoever he doeth shall prosper" (Psalm 1: 1-3).

"O God! Thou art my God; early I will seek thee: My soul long eth for thee, how shall I stretch my flesh in a dry thirsty land, where no tree and water" (Psalm 63: 1-2).
"And by the river upon the bank thereof, on this side, on that side, shall grow all trees for meat, whose leaf shall not fade neither shall the fruits thereof be consumed: it shall bring forth new fruit according to his months that is twelve times in the year, because their waters they issued out of the sanctuary, and the fruit there of shall be for food and the leaf for medicine" (Ezek 47:12). This is the religious milieu in tree planting and preserving tradition of Ethiopian Orthodox Tewahido Church.

Therefore, Churches must be furnished and adorned with graceful trees and beautiful gardens. 'Gardening was the first kind of employment on record in which man was engaged. Though trees and plants produced the necessary flower and fruits by the will of God, dressing and keeping were necessary to maintain the different kinds of trees and plants in their perfection. To cultivate, keep and preserve the garden from all intruders was the duty of man. It is not conceivable that man could have been happy if inactive. God gave him work to do to get his bread distributed to his happiness; for the structure of his body as well as his mind plainly proves that he was never intended for a merely contemplative life' [9]. This is the commandment considered and practiced most in the monastic life of Ethiopian Orthodox Tewahedo Church.

There is no published research on mountain conservation imaginative tradition of Ethiopian orthodox tewahedo Church. However, from existing knowledgeable church scholars, 'Mountains are whispered symbol of strength and stability; signify places or sources of strength, the strength of the kingdom of God, the righteousness of God, persons in authority and difficulties, Mighty kings and kingdoms are symbolized as the tall mountain'. Aligned with thoughts and teaching most of the Ethiopian Orthodox Tewahido churches and monasteries are built on hills, mountains and high places with dense forest.

In procession with divine aspects, plants in monasteries offer several material benefits for monastic community; sources of fuel wood that is required for services of the church, provide shade from the sizzling sun for the clergy, laity during mass and religious festivals, stems of the standing trees give support to individuals during prays, add aesthetic value to the church and hermits and monks used as praying sanctuary, feed on the leaves, fruits and other parts of the wild plants [73].

In generally, the significant material and service importance of trees and forests in church and monasteries compound prioritized by church scholars; respect to God's place, grace for the churches and monasteries, microclimate amelioration, resting places and sanctuaries for saints, serve as traditional church schools (learning and teaching under the shade of trees), soil erosion control, provide sweet aroma and odour to the church, serve to justify land ownership. In addition, trees and forests around churches and monasteries symbolise the fact that God created Adam and placed him in Eden; trees and forests around churches and monasteries symbolise the appearance of God to Abraham under a tree; trees and forests around churches and monasteries symbolise the faithful laity; trees and forests around churches and monasteries are symbols for life after death; church and monasteries forests are used as symbols or examples in the teaching or propagation of Gospel; church and monasteries forests are national heritage; churches and monasteries are holy places as they are houses of God, therefore, forests and trees grown in God's compounds are considered as sacred, and trees and forests in the church and monastery compound are symbolic of the presence of angels guarding the church. Therefore, it is precious heritages passed from many generations with 
Citation: Tura TT, Soromess T, Argaw M, Leta S (2017) Holy Hills Role in Biodiversity Conservation and Mountain Management: Implication of Multi-Purpose Ethiopian Orthodox Tewahido Church in Sustainable Mountain Conservation. J Biodivers Endanger Species 5: 179. doi: $10.4172 / 2332-2543.1000179$

Page 9 of 10

the sacrifice of holy fathers and mothers. They have got blessings of many saints beneath their roots where their holy flesh rested in peace.

\section{Conclusion and Recommendation}

Most of global community perception is directly and indirectly relay on their respective religions, cultures and taboos. Those religions, cultures and taboos allied implicitly with nature; particularly forest, mountain and water body directly and indirectly. Therefore, considering those social institutions in nature conservation is a central point. In the similar way the review revealed that sacred grove in general church forest in particular play significant role in mountain ecology management, biodiversity conservation and climate change mitigation. Therefore, world and regional mountain initiative, conservation organizations, development agents, donors and researchers recommended working with sacred grove resources and indigenous knowledge behind those resources in order to preserve our common future from illegal intruder. In addition world sacred grove association, world indigenous knowledge society, respective scientist and organization on the area strongly recommended to promote and consult policy formulator on equal importance of sacred grove knowledge with western science in nature conservation in order to preserve our remnant forest and conservation activity success.

\section{References}

1. Ellen R, Harris $H(2000)$ Introductionindigenous environmental knowledge and its transformations. Amsterda Harwood Academic, pp: 1-33.

2. Ericksen PJ, Ardon M (2003) Similarities and differences between farmer and scientist views on soil quality issues in central Honduras. Geoderma 111: 233-224

3. Appleton H, Fernandez ME, Hill CLM, Quiroz C (1995) Claiming and using indigenous knowledge. In missing links, gender equity in science and technology for development. Int Dev Res Centre (IDRC), pp: 55-83.

4. Appleton H, Fernandez ME, Hill CLM (2001) Claiming and using indigenous knowledge, Chapter 3. Can Int Dev Res Centre.

5. Prado J, Weber C (2003) Facilitating the way for implementation of sustainable forest management. The Case of Chile Institu to Forestal (INFOR), Santiago, Chile.

6. Bhattarya S, Tripathi N (2004) Integrating indigenous knowledge and GIS for participatory natural resource management: state-of-the-practice. The electronic 30. J Inf Syst Dev Countries.

7. De Walt BR (1994) Using indigenous knowledge to improve agriculture and natural resource management. Human Organisation 53: 123-131.

8. Cleaver F (1999) Paradoxes of participation: questioning participatory approaches to development. J Int Dev 11: 597-612.

9. Alemayehu W (2002) Opportunities, constraints and prospects of ethiopian orthodox tewahido churches in conserving forest resources: the case of churches in south gonder, northern ethiopia. Swedish University of Agricultural Sciences, Skinnskatterberg, Sweden.

10. Aymro W, Motovu J (1970) The ethiopian orthodox church. The Ethiopian Orthodox Mission, Addis Ababa, Ethiopia.

11. Sibanda B (1997) Governance and the environment: The role of african religion in sustainable utilization of natural resources in zimbabwe. Forests Trees and People Newsletter (FAO) (Sweden), 34: 27-31

12. Central Statistical Agency (2007) Statistical abstract of ethiopia, Addis Ababa Ethiopia.

13. Food and Agriculture Organization of the United Nations (1984b) Assistance to Land use Planning in Ethiopia. Land use, Production Regions and Farming Systems Inventory. Tech Report 3, Rome.

14. Constable M (1984) Resources of rural development in Ethiopia. Ethiopian Highly lands Biodiversity: A Complementary Contribution to the Global Biodiversity Assessment. Biogeogr 12: 89-92.

15. Food and Agriculture Organization of the United Nations (1984a) Agro climatic Resource Inventory for Land use Planning. Ethiopia. Tech Report 2, Rome.
16. Zerihun W (1999) Vegetation map of Ethiopia. Addis Ababa University Addis Ababa, Ethiopia Institute of Biodiversity Conservation and Research, Addis Abeba, Ethiopia.

17. Ministry of Agriculture (2000). Agro ecological Zonations of Ethiopia. Addis Ababa, Ethiopia.

18. Gadgil M, Vartak VD (1976) The sacred groves of Western Ghats in India. Econ Botany 30: 152-160.

19. Colding J, Folke C (1997) The Relations among Threatened Species, Their Protection, and Taboos. Conserv Ecol.

20. Irons W (1996) Morality, religion and human evolution. Religion and science, History, method, dialogue, Routledge NY, USA, pp: 375-399.

21. Brown J, Mitchel N (2000) Culture and nature in the protection of Andean landscapes. Biodiversity Conservation 6: 1007-1026.

22. Sosis, R, Bressler ER (2003) Cooperation and commune longevity: A test of the costly signaling theory of religion. Cross Cultural Research 37: 211-239.

23. Brown K (2003) Three challenges for a real people-centred conservation. Global Ecology Bulbulia, J Charismatic signalling. Journal for the Study of Religion, Nature and Culture 3: 518-551.

24. Gadgil M, Vartak VD (1975) Sacred groves of India: a plea for continued conservation. J Bombay Natl His Soc 72: 314-320.

25. Martin B (2000) Sacred mountains, religious paradigms, and identity among the Mescalero actions. N Resour 31: 741-756.

26. Baker I (2004) The Heart of the World: A Journey to the Last Secret Place. The Penguin Press, New York.

27. Chandrakanth MG, Romm J (1991) Sacred forests, secular forest policies and people's actions. N Resour 31: 741-756.

28. Lebbie A, Freudenberger M (1996) Sacred groves in Africa: forest patches in transition. Forest Patches in Tropical Landscapes. Island Press, Washington, DC, USA, pp: 300-324.

29. Millar D, Aniah R, Atoyure $P$ (1999) Shrines and groves. Compass newsletter Cultural and Spiritual Values of Biodiversity: A Complementary Contribution to the Global Biodiversity Assessment. United Nations Environ Programme, Nairobi, Kenya, pp: 382-385.

30. Mgumai FH, Oba G (2003) Potential role of sacred groves in biodiversity conservation in Northwestern Belize. Antiquity 73: 650-660.

31. Ramanujam MP, Cyril KPK (2003) Woody species diversity of four sacred groves in the Pondicherry region of South India. Biodiversity Conservation 12: 289-299.

32. Ghate V, Sane H, Ranade SS (2004) Focus on Sacred Groves and Ethnobotany Prism Public, Mimbai.

33. Engel JR (1985) Biosphere reserves as sacred places. Orion Nature Quar 4 53-59.

34. Mathew S, Boyd R (2011) Punishment sustains large-scale cooperation in prestate warfare. Proc Nat Acad Sci (USA) 108: 11375-11380.

35. Boyd R, Richerson PJ (1992) Punishment allows the evolution of cooperation (or anything else) in sizable groups. Ethol Sociobiol 13: 171-195.

36. Moller H, Berkes F, Lyver PO, Kislalioglu M (2004) Combining science and traditional ecological knowledge: monitoring populations for co-management. Ecol Soc 9: 2 .

37. Johnson DDP, Kru O (2004) The good of wrath: Supernatural punishment and the evolution of cooperation. Polit Theol 5: 159-176.

38. Johnson DDP (2005) God's punishment and public goods: A test of the supernatural punishment hypothesis in 186 world cultures. Human Nature 16 410-446.

39. Atkinson QD, Bourrata P (2011) Beliefs about God, the afterlife and morality support the role of supernatural policing in human cooperation. Evol Human Behav 32: 41-49.

40. Rudiak GP (2012) Promiscuous corroboration and climate change translation: a case study from the Marshall Islands. Global Environmental Change 22: 46-54.

41. Leduc T (2010) Climate, Culture, Change: Inuit and Western Dialogues with a Warming North University of Ottawa Press, Quebec, Canada. 
Citation: Tura TT, Soromess T, Argaw M, Leta S (2017) Holy Hills Role in Biodiversity Conservation and Mountain Management: Implication of Multi-Purpose Ethiopian Orthodox Tewahido Church in Sustainable Mountain Conservation. J Biodivers Endanger Species 5: 179. doi: $10.4172 / 2332-2543.1000179$

Page 10 of 10

42. Allison $E$ (2015) The spiritual significance of glaciers in an age of climate change WIREs Climate Change Apache. Worldviews, Environment Cultural Religion 4: 264-282.

43. Barnett $L$ (2015) The theology of climate change: sin as agency in the Enlightenment's. Anthropocene Environmental History 20: 217-237.

44. Northcott MS (2007) Moral climate: the ethics of global warming Dartman, Longman and Todd. Ltd/Orbis, London, pp: 336

45. Wilkinson KR (2010) Climate's salvation: why and how American evangelicals are engaging with climate change. Environment March/April pp: 47-57.

46. Albertson D, King C (2010) Without nature:A new condition for theology. Fordham University Press NY, USA, p: 469.

47. Clingerman $F$ (2015) Roundtable on climate destabilization and the study of religion: Theologians as interpreters not prophets in a changing climate. J Am Academy Relig.

48. Hulme M (2015) Better weather: The cultivation of the sky. Cultural Anthropology 30: 236- 244.

49. Jenkins W (2005) Assessing metaphors of agency: Intervention, perfection and care as models of environmental practice. Environ Ethic 27: 135-154.

50. Gifford R, Kormos C, Mclntyre A (2015) Behavioral dimensions of climate change: drivers, responses, barriers, and interventions. WIREs Climate Change 2: 801-827.

51. Castro V, Aldunate C (2003) Sacred mountains in the higlands of the southcentral Andes. Mount Res Dev 23: 73-79.

52. Verran H (1998) Re-imagining land ownership in Australia. Postcolonial Stud Cult Poli Econ 1: 237-254.

53. Liu H, Xu Z, Xu Y, Wang J (2002) Practice of conserving plant diversity through traditional beliefs: a case study in Xishuangbanna, southwest China. Biodiversity Conservation 11: 705-713.

54. Godbole A (1996) Role of tribals in preservation of sacred forests. Ethnobiology in Human Welfare. Deep Publications, New Delhi, India, pp: 345-348.

55. Byers BA, Cunliffe R, Hudak AT (2001) Linking the conservation of culture and nature: Reclamation study. Working paper 17, FAO/Ministry of Agriculture, Addis Ababa, Ethiopia.

56. Virtanen $P$ (2002) The role of customary institutions in the conservation of biodiversity: sacred forests in Mozambique. Environmental Values 11: 227-241.

57. Miehe G, Miehe S, Koch K, Will M (2003) Sacred forests in Tibet: using geographical information systems for forest rehabilitation. Mountain Research Development 23: 324-328.

58. Nair NC (1981) On the rediscovery of four threatened species from sacred groves of Kerala. J Econ Taxon Bot 2: 233-234.

59. Decher J (1997) Conservation, small mammals, and the future of sacred groves in West Africa. Tanzania Environmental Conservation 30: 259-265.

60. Carol JPC, Reed LW (2004) Sacred forest, hunting, and conservation in west Kalimantan, Indonesia. Human Ecology 32: 313-338.
61. Lhalungpa L (1990) Tibetan history. White Lotus. Snow Lion Publications, Ithaca, NY, USA, p: 32

62. Salick J, Anderson D, Woo J, Sherman R, Cili N, et al. (2004) Tibetan Ethnobotany and Gradient Analyses: Menri (Medicine Mountains), Eastern Himalayas.

63. Anderson DM, Salick J, Moseley RK, Xiaokun O (2005) Conserving the sacred medicine mountains: a vegetation analysis of Tibetan sacred sites in Northwest Yunnan. Ann Missouri Bot Garden 82: 34-46.

64. Sperber G (1994) Bäume in der Bibel. J Forstw Cbl 113: 12-34

65. Ormsby A, Ormsby C (2010) Tafiatome monkey sanctuary, ghana: Communitybased ecotourism at a sacred site. In Sacred Natural Sites: Conserving Nature and Culture, Routledge, Geneva, Switzerland.

66. Cardelús CL, Lowman MD, Alemaheyu W (2012) Uniting church and science for conservation. Science 335: 915-917.

67. Zewde B (1997) The Forests of wallo In Historical perspective: With a Focus on the Yagof State forest. Paper prepared for the Conference on "Environmental and Development" DebreZeit, pp: 12-14.

68. Cohen JM, Weintraub D (1975) Land and Peasants in Imperial Ethiopia: The Social Background to a Revolution. Van Goreum \& Assen, The Netherlands.

69. Klein RJT, Nicholls RT, Mimura N (1999) Coastal Adaptation to Climate Change: Can the IPCC Technical Guidelines be applied. Mitigation and Adaptation Strategies for Global Change 4: 239-252.

70. Smit B, Pilifosova O (2003) From adaptation to adaptive capacity and vulnerability reduction. Climate Change, Adaptive Capacity and Developmen. Imperial College London, Press, pp: 9-28.

71. Moser SC, Dilling $L$ (2007) Toward the social tipping point: creating a climate for change, in. Creating a Climate for Change, Communicating Climate Change and Facilitating Social Change. Cambridge University Press, pp: 491-516.

72. Smit B, Wandel J (2006) Adaptation, Adaptive Capacity and Vulnerability. Global Environmental Change 16: 282-292.

73. Taye B (1998) Biodiversity Conservation: Experience of the Ethiopian Orthodox Tewahido Church. MSc in Forestry Graduates Magazine, pp: 1994-1998.

74. White $F$ (1983) The vegetation of Africa, a descriptive memoir to accompany the UNESCO/AETFAT/UNSO vegetation map of Africa. UNESCO. Nat Resou Res 20: 1-356.

75. Friis I (1992) Forests and forest trees of northeast tropical Africa. Kew Bulletin Additional series No. 1, HMSO, London, UK.

76. Melaku B (1992) Forest History of Ethiopia from Early times to 1974. Journal of the Ethiopian Wildlife and Natural History Society 19: 3-9

77. Flora of Tropical East Africa (1996) continuing. The royal botanical gardens Kew, Great Britain and the East African Herbarium, Nairobi, KE.

78. Millennium Ecosystem Assessment. Bridging Scales and Epistemologies: Linking Local Knowledge and Global Science in Multi-Scale Assessments. Bibliotheca Alexandria, Alexandria, Egypt.

79. Upadhaya K, Pandey HN, Law PS, Tripathi RS (2003) Tree diversity in sacred groves of the Jaintia hills of Meghalaya, northeast India. Biodiversity Conservation 12: 583-597. 